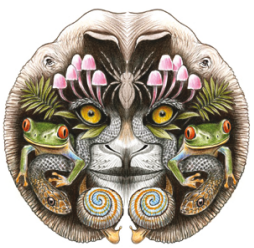

ISSN

Online 0974-7907

Print 0974-7893

\title{
DISTRIBUTION, THREATS AND CONSERVATION STATUS OF THE WAYANAD MAHSEER, NEOLISSOCHILUS WYNAADENSIS (DAY, 1873) (TELEOSTEI: CYPRINIDAE): AN ENDEMIC LARGE BARB OF THE WESTERN GHATS, INDIA
}

\section{OPEN ACCESS}

Anvar Ali ${ }^{1}$, Neelesh Dahanukar ${ }^{2}$, Siby Philip ${ }^{3}$, K. Krishnakumar ${ }^{4}$ \& Rajeev Raghavan ${ }^{5}$

1,3,4,5 Conservation Research Group (CRG), St. Albert's College, Kochi, Kerala 682018, India ${ }^{2}$ Indian Institute of Science Education and Research (IISER), Dr. Homi Bhabha Road, Pashan, Pune, Maharashtra 411008, India ${ }^{2,5}$ Systematics, Ecology \& Conservation Laboratory, Zoo Outreach Organization (ZOO), 96 Kumudham Nagar, Vilankurichi Road, Coimbatore, Tamil Nadu 641035, India

${ }^{3}$ Department of Zoology, Nirmalagiri College, Koothuparambu, Kannur, Kerala 670701, India ${ }^{5}$ Mahseer Trust, c/o The Freshwater Biological Association, East Stoke River Laboratory, Wareham, Dorset, BH20 6BB, United Kingdom ${ }^{1}$ anvaraliif@gmail.com, ${ }^{2}$ n.dahanukar@iiserpune.ac.in, ${ }^{3}$ philipsiby@gmail.com, ${ }^{4}$ kkaqua@gmail.com, ${ }^{5}$ rajeevraq@hotmail.com (corresponding author)

\begin{abstract}
The Wayanad Mahseer Neolissochilus wynaadensis (Day, 1873) is an endemic cyprinid fish that occurs in the upland streams and rivers of the southern region of the Western Ghats. This species has been listed as 'Critically Endangered' on the IUCN Red List of Threatened Species due to its restricted distribution and heavy declines in populations. Like many large cyprinids of the Western Ghats, N. wynaadensis is poorly known and documented, with very few verified records and voucher specimens. Based on specimens recently collected from Wayanad, Kerala, the type locality, as well as two additional locations in the Kodagu District of Karnataka; we provide information on the current distribution, phylogenetic position, threats and conservation. An updated conservation assessment of this species following the IUCN Red List categories and criteria is also provided.
\end{abstract}

Keywords: Barbodes, Coorg, freshwater fish, Vulnerable.

Abbreviations: BMNH - Natural History Museum, London; CRG-SAC - Conservation Research Group, St. Albert's College, Kochi; FMNH - Field Museum, Chicago.

DOI: http://dx.doi.org/10.11609/JoTT.o3901.5686-99 | ZooBank: urn:Isid:zoobank.org:pub:DB1F3C62-C246-4F9A-86E0-A1A863E4009E

Editor: Anjana Silva, Rajarata University of Sri Lanka, Saliyapura, Sri Lanka.

Date of publication: 26 May 2014 (online \& print)

Manuscript details: Ms \# o3901 | Received 02 January 2014 | Final received 19 April 2014 | Finally accepted 15 May 2014

Citation: Ali, A., N. Dahanukar, S. Philip, K. Krishnakumar \& R. Raghavan (2014). Distribution, threats and conservation status of the Wayanad Mahseer, Neolissochilus wynaadensis (Day, 1873) (Teleostei: Cyprinidae): an endemic large barb of the Western Ghats, India. Journal of Threatened Taxa 6(5): 5686-5699; http:// dx.doi.org/10.11609/JoTT.03901.5686-99

Copyright: ( ) Ali et al. 2014. Creative Commons Attribution 4.0 International License. JoTT allows unrestricted use of this article in any medium, reproduction and distribution by providing adequate credit to the authors and the source of publication.

Funding: Rajeev Raghavan thanks the Mohammed Bin Zayed Species Conservation Fund (MBZSCF; Project 1225670) and the North of England Zoological Society (NEZS), Chester Zoo for funding the project on 'Lost fishes of the Western Ghats'. Neelesh Dahanukar is supported by the Inspire Faculty Fellowship of the Department of Science and Technology (DST), Government of India.

Competing Interest: The authors declare no competing interests. Funders had no role in study design, collection, analysis and interpretation of data and manuscript writing.

Author Contribution: AA, ND, SP, KK \& RR carried out the field work and collected the specimens; RR studied museum specimens; AA performed morphometry, ND carried out the extraction of DNA and related molecular laboratory work; SP carried out the phylogenetic analysis; AA, SP, ND \& RR wrote the manuscript.

Acknowledgements: The authors thank the president and members of the Coorg Wildlife Society (CWS), Madikeri, especially P. Aiyappa (Shyam), for their excellent hospitality, support and assistance during the field work in Kodagu; Jörg Freyhof, Toplitzin Contreras MacBeath, Nikhil Sood, Roy Boppana, Baby Ganapathy, Naushad, Fibin Baby, Keerthi Krutha and Sahila Kudalkar were excellent companions during various phases of field work. Rajeev Raghavan thanks Ralf Britz for useful discussions, and his help during visits to Natural History Museum (NHM), London; Leo Smith and Kevin Swagel for images of the syntypes from Field Museum (FMNH), Chicago; Steven Lockett and Mark Everard for helpful insights on the collection sites and for sharing their images; Kevin Conway for relevant literature, and Rohan Pethiyagoda and J.D. Marcus Knight for sharing information on the genus Neolissochilus.

ज6ק

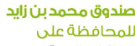

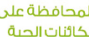

لكائنات الحيةً The Mohamed bin Zayed
SPECIIS CONSEVVATION ENIND
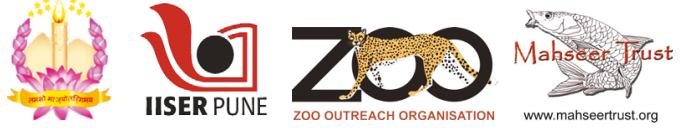


\section{INTRODUCTION}

The cyprinid genus, Neolissochilus Rainboth, 1985, comprises of 25 species of medium to large sized barbs, of which 22 are known to occur in Southeast Asia (see Kottelat 2013) and seven in the Indian subcontinent (Table 1). They are important game fishes in parts of South and Southeast Asia (Jhingran 1977; Khaironizam 2010) and are also known to occur in the aquarium pet trade (Khaironizam 2010). Sixteen species of Neolissochilus have been assessed for their conservation status, of which, two species have been assessed as 'Critically Endangered', two as 'Vulnerable', three as 'Near Threatened', four as 'Least Concern' and five as 'Data Deficient' (see Table 1; and also species specific accounts on IUCN Red List of Threatened Species at www.iucnredlist.org).

The Wayanad Mahseer, Neolissochilus wynaadensis (Day, 1873) is one of two species within the genus that occurs in peninsular India; the other being N. bovanicus, found in the Bhavani River. Day (1873; p528) described Barbus (Barbodes) wynaadensis, from Vythiri, Wayanad and reported it to be a common species in the larger streams of the region, growing up to a length of $200 \mathrm{~mm}$ (also see Day 1878, p 568; 1889, p 313). The species was considered to be endemic to the streams in the Wayanad region of Kerala, until Manimekalan (1998) and subsequently, Yazdani et al. (2001) recorded it from Mudumalai, Tamil Nadu and Arunachalam et al. (2005) recorded it from Abbey Falls near Madikeri, Kodagu, Karnataka.

Neolissochilus wynaadensis has been considered to be a rare species with several surveys in and around the type locality, failing to collect this species, and very few records available in the recent ichthyological literature which are backed by voucher specimens (see Abraham 2011). Due to its restricted distribution and severe population declines (up to $80 \%$ ) in the last decade, $N$. wynaadensis has been listed as 'Critically Endangered' in the IUCN Red List of Threatened Species (Abraham 2011).

As part of the on-going project on the 'Lost fishes of Western Ghats', which aims to document the status and distribution of the region's rarest species (see Ali et al. 2013 a,b,c) we obtained specimens of $N$. wynaadensis (Image $1 \mathrm{a}, \mathrm{b}, \mathrm{c}$ ) from its type locality (Wayanad) as well as several locations in Kodagu District, Karnataka. This paper serves to document these records, and discuss the current distribution, threats and conservation status of this species. In the wake of this new information, we also propose a revised Red List status for $N$. wynaadensis.
Table 1. List of valid species within the genus Neolissochilus Rainboth 1985, their distribution and IUCN threat status

\begin{tabular}{|c|c|c|}
\hline Species & Distribution & IUCN Status \\
\hline $\begin{array}{l}\text { Neolissochilus baoshanensis (Chen } \\
\text { \& Yang, 1999) }\end{array}$ & China & Data Deficient \\
\hline $\begin{array}{l}\text { Neolissochilus benasi (Pellegrin \& } \\
\text { Chevey, 1936) }\end{array}$ & China, Vietnam & Data Deficient \\
\hline $\begin{array}{l}\text { Neolissochilus blanci (Pellegrin \& } \\
\text { Fang, 1940) }\end{array}$ & $\begin{array}{l}\text { Cambodia, Laos, } \\
\text { Thailand, Vietnam }\end{array}$ & \begin{tabular}{|l|} 
Near \\
Threatened
\end{tabular} \\
\hline Neolissochilus blythi (Day, 1870) & Myanmar & Data Deficient \\
\hline $\begin{array}{l}\text { Neolissochilus bovanicus*(Day, } \\
\text { 1877) }\end{array}$ & India & $\begin{array}{l}\text { Critically } \\
\text { Endangered }\end{array}$ \\
\hline $\begin{array}{l}\text { Neolissochilus compressus (Day, } \\
1870 \text { ) }\end{array}$ & $\begin{array}{l}\text { Uncertain - probably } \\
\text { Myanmar }\end{array}$ & Not Assessed \\
\hline Neolissochilus dukai (Day, 1878) & India & Data Deficient \\
\hline $\begin{array}{l}\text { Neolissochilus hendersoni (Herre, } \\
\text { 1940) }\end{array}$ & Malay Peninsula & Not Assessed \\
\hline $\begin{array}{l}\text { Neolissochilus heterostomus (Chen } \\
\text { \& Yang, 1999) }\end{array}$ & China & Not Assessed \\
\hline $\begin{array}{l}\text { Neolissochilus hexagonolepis } \\
\text { (McClelland, 1839) }\end{array}$ & $\begin{array}{l}\text { Bangladesh, China } \\
\text { India, Indonesia, } \\
\text { Malaysia, Myanmar, } \\
\text { Nepal, Thailand }\end{array}$ & Not Assessed \\
\hline $\begin{array}{l}\text { Neolissochilus hexastichus } \\
\text { (McClelland, 1839) }\end{array}$ & India, Myanmar & $\begin{array}{l}\text { Near } \\
\text { Threatened }\end{array}$ \\
\hline $\begin{array}{l}\text { Neolissochilus longipinnis (Weber \& } \\
\text { Beaufort, 1916) }\end{array}$ & Sumatra and Java & Not Assessed \\
\hline $\begin{array}{l}\text { Neolissochilus nigrovittatus } \\
\text { (Boulenger, 1893) }\end{array}$ & Myanmar & Data Deficient \\
\hline $\begin{array}{l}\text { Neolissochilus paucisquamatus } \\
\text { (Smith, 1945) }\end{array}$ & Myanmar, Thailand & Least Concern \\
\hline $\begin{array}{l}\text { Neolissochilus soro (Valenciennes, } \\
1842 \text { ) }\end{array}$ & Indonesia & Not Assessed \\
\hline $\begin{array}{l}\text { Neolissochilus soroides (Duncker, } \\
\text { 1904) }\end{array}$ & $\begin{array}{l}\text { Cambodia, Malaysia, } \\
\text { Thailand }\end{array}$ & Least Concern \\
\hline $\begin{array}{l}\text { Neolissochilus spinulosus } \\
\text { (McClelland, 1845) }\end{array}$ & India & Data Deficient \\
\hline $\begin{array}{l}\text { Neolissochilus stevensonii (Day, } \\
\text { 1870) }\end{array}$ & Myanmar & Data Deficient \\
\hline Neolissochilus stracheyi (Day, 1871) & $\begin{array}{l}\text { Cambodia, Myanmar, } \\
\text { India, Thailand }\end{array}$ & Least Concern \\
\hline $\begin{array}{l}\text { Neolissochilus subterraneus } \\
\text { Vidthayanon \& Kottelat, } 2003\end{array}$ & Thailand & Vulnerable \\
\hline $\begin{array}{l}\text { Neolissochilus sumatranus (Weber } \\
\& \text { Beaufort, 1916) }\end{array}$ & Indonesia, Thailand & Not Assessed \\
\hline $\begin{array}{l}\text { Neolissochilus thienemmani (Ahl, } \\
\text { 1933) }\end{array}$ & Indonesia & Vulnerable \\
\hline $\begin{array}{l}\text { Neolissochilus tweediei (Herre \& } \\
\text { Myers, 1937) }\end{array}$ & Malaysia & Not Assessed \\
\hline $\begin{array}{l}\text { Neolissochilus vittatus (Smith, } \\
\text { 1945) }\end{array}$ & Myanmar, Thailand & Least Concern \\
\hline $\begin{array}{l}\text { Neolissochilus wynaadensis (Day, } \\
\text { 1873) }\end{array}$ & India & $\begin{array}{l}\text { Critically } \\
\text { Endangered }\end{array}$ \\
\hline
\end{tabular}

*generic status as per Pethiyagoda et al. (2012)

\section{MATERIALS AND METHODS}

\section{Materials examined}

Neolissochilus wynaadensis, CRG-SAC.2013.109-110, 07.x.2013, 2 ex., 126.45-139.83 mm SL, off the road from Mukkodlu to Surlabi, Kodagu, $12.501^{\circ} \mathrm{N} \&$ $75.757^{\circ} \mathrm{E}$, Cauvery River, Karnataka, India, coll. Raghavan 


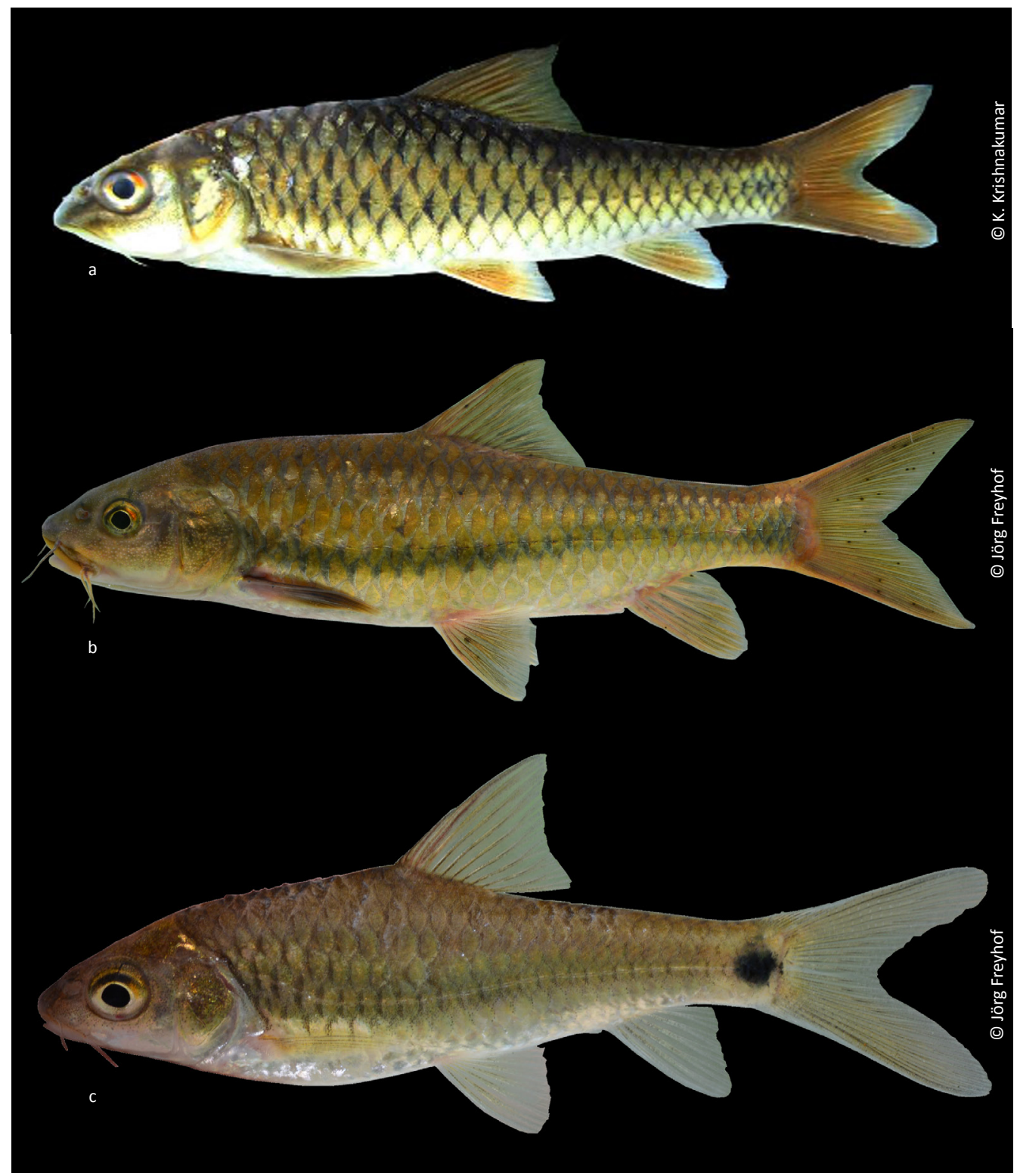

Image 1. Neolissochilus wynaadensis from Kodagu and Wayanad; (a) freshly preserved adult specimen from Thirunelli, Wayanad [CRGSAC.2013.113; $83.97 \mathrm{~mm} \mathrm{SL}$; (b) live adult specimen from near Mukkodlu, Kodagu [CRG-SAC.2013.109; 126.45mm SL]; (c) live juvenile specimen from near Bhagamandala, Kodagu [not preserved] [images not to scale]

et al.; Neolissochilus wynaadensis, 08.x.2013, CRGSAC.2013.111-112, 2 ex., 114.85-130.03 mm SL, off the road from Bhagamandala to Napoklu, $12.329^{\circ} \mathrm{N}$ \& $75.659^{\circ} \mathrm{E}$, Cauvery River, Karnataka, India, coll. R. Raghavan et al.; Neolissochilus wynaadensis, CRGSAC.2013.113-114, 11.x.2013, 2 ex., 83.97-84.48 mm $\mathrm{SL}$, Thirunelli, $11.902^{\circ} \mathrm{N} \& 75.998^{\circ} \mathrm{E}$, Kalindi Stream of Kabini River, Wayanad, Kerala, India, coll. A. Ali \& K. Krishnakumar.

Photographs: Barbus wynaadensis, F. Day, BMNH 1889.2.1.571, 1 ex, Vythiri, Wayanad, India; Barbus wynaadensis, F. Day, FMNH 2318, 1 ex, Vythiri, Wayanad,
India (both paralectotypes) (Image 2 a,b).

\section{Biometrics}

Counts and measurements follow Pethiyagoda et al. (2008, 2012). Measurements were taken using a digital calliper to the nearest $0.1 \mathrm{~mm}$. Subunits of body are presented as percent of standard length (SL) and subunits of head are provided as percent of head length (HL) (see Table 2).

\section{DNA isolation and molecular phylogeny}

Fin clips were extracted from fresh specimens 


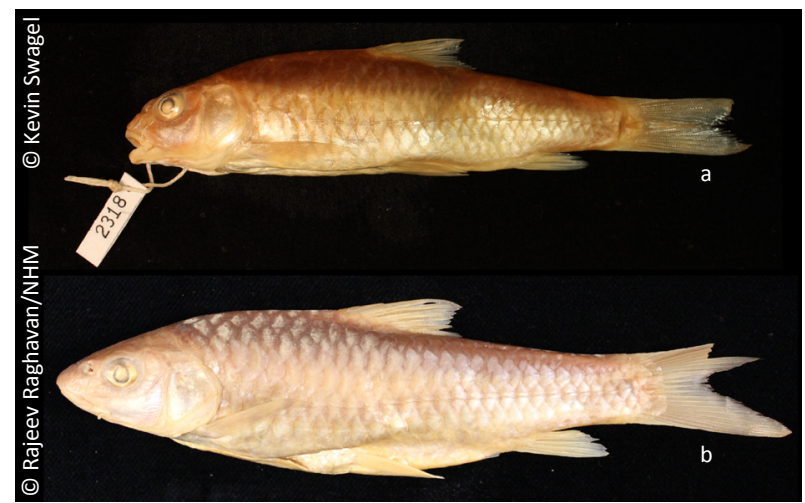

Image 2. Paralectotypes and or Day's specimens of Neolissochilus wynaadensis; (a) FMNH 2318 and (b) 1889.2.1.571 collected from three different locations (one of which was from the type locality) in the Cauvery drainage (see Table 3) and was preserved in absolute ethanol. Laboratory protocols for DNA isolation, PCR amplification of co1 and cytb genes, and molecular phylogeny are similar to those detailed in Ali et al. $(2013 a, c)$.

Table 2. Morphometric characters and meristics of Neolissochilus wynaadensis from various locations in the Western Ghats

\begin{tabular}{|c|c|c|c|c|c|c|}
\hline Morphometric characters & $\begin{array}{c}\text { CRG.SAC.2013. } \\
109\end{array}$ & $\begin{array}{c}\text { CRG.SAC.2013. } \\
110\end{array}$ & $\begin{array}{c}\text { CRG.SAC.2013. } \\
111\end{array}$ & $\begin{array}{c}\text { CRG.SAC.2013. } \\
112\end{array}$ & $\begin{array}{c}\text { CRG.SAC.2013. } \\
113\end{array}$ & $\begin{array}{c}\text { CRG.SAC.2013. } \\
114\end{array}$ \\
\hline Standard Length (SL) in mm & 139.8 & 126.5 & 130.0 & 114.9 & 84.5 & 84.0 \\
\hline \multicolumn{7}{|l|}{$\% \mathrm{SL}$} \\
\hline Head length (HL) & 28.1 & 28.7 & 26.0 & 29.2 & 28.1 & 28.6 \\
\hline Head depth & 18.8 & 19.2 & 18.8 & 20.8 & 19.2 & 20.1 \\
\hline Pre dorsal length & 51.0 & 50.3 & 48.6 & 49.0 & 49.7 & 49.8 \\
\hline Pre anal length & 76.3 & 75.8 & 75.2 & 76.8 & 74.8 & 75.3 \\
\hline Pre pelvic length & 52.9 & 52.2 & 50.8 & 55.0 & 50.9 & 51.8 \\
\hline Body depth & 26.5 & 26.2 & 25.9 & 25.1 & 26.9 & 27.1 \\
\hline Caudal peduncle length & 18.0 & 17.5 & 18.2 & 18.8 & 19.1 & 19.6 \\
\hline Caudal peduncle depth & 10.9 & 10.9 & 10.7 & 10.7 & 11.1 & 11.5 \\
\hline Dorsal fin height & 22.5 & 23.4 & 22.8 & 22.4 & 23.2 & 23.4 \\
\hline Pectoral fin length & 20.7 & 19.7 & 18.9 & 19.7 & 20.2 & 20.0 \\
\hline Pelvic fin length & 17.6 & 16.9 & 16.4 & 16.9 & 18.2 & 18.4 \\
\hline Anal fin length & 20.3 & 20.0 & 18.0 & 18.6 & 20.0 & 19.4 \\
\hline Dorsal hypural distance & 53.3 & 53.0 & 55.0 & 53.7 & 56.2 & 56.4 \\
\hline Anal fin base length & 8.8 & 9.2 & 8.0 & 8.8 & 7.8 & 8.3 \\
\hline Dorsal fin base length & 15.1 & 15.7 & 14.9 & 14.2 & 16.3 & 15.5 \\
\hline \multicolumn{7}{|l|}{$\% \mathrm{HL}$} \\
\hline Snout length & 37.0 & 38.3 & 40.9 & 39.4 & 36.2 & 35.9 \\
\hline Head depth & 66.9 & 67.0 & 72.4 & 71.0 & 68.5 & 70.3 \\
\hline Eye diameter & 24.3 & 25.7 & 27.5 & 26.0 & 28.5 & 28.3 \\
\hline Maxillary barbel length & 26.8 & 27.4 & 30.0 & 27.7 & 26.7 & 27.4 \\
\hline Internarial width & 20.8 & 18.8 & 20.4 & 18.6 & 20.7 & 18.3 \\
\hline Inter orbital width & 35.0 & 34.5 & 36.5 & 36.0 & 36.2 & 33.7 \\
\hline \multicolumn{7}{|l|}{ Meristics } \\
\hline Dorsal fin rays & iv 9 & iv 9 & iv 9 & iv 9 & iv 9 & iv 9 \\
\hline Pectoral fin rays & i 14 & i 14 & i 14 & i 14 & i 14 & ¡ 14 \\
\hline Ventral fin rays & i 8 & i 8 & i 8 & i 8 & i 8 & i 8 \\
\hline Anal fin rays & iii 5 & iii 5 & iii 5 & iii 5 & iii 5 & iii 5 \\
\hline Lateral line scales & $28+1$ & $28+1$ & $28+1$ & $29+1$ & $26+1$ & $26+1$ \\
\hline Lateral transverse scales & $1 / 242 \frac{1}{2}$ & $1 / 242 \frac{1}{2}$ & $1 / 2421 / 2$ & $1 / 242 \frac{1}{2}$ & $1 / 242 \frac{1}{2}$ & $1 / 242 \frac{1}{2}$ \\
\hline Pre-dorsal scales & 10 & 9 & 9 & 9 & 9 & 9 \\
\hline Circumpeduncular scales & 12 & 12 & 12 & 12 & 12 & 12 \\
\hline
\end{tabular}




\section{RESULTS AND DISCUSSION}

\section{Taxonomy and generic status}

Neolissochilus wynaadensis has been placed in different genera, viz.: Barbus (Barbodes) (Day 1873, 1878, 1889), Barbus (Puntius) (Hora \& Law 1941), Puntius (Tonapi \& Mulherkar 1963; Jayaram 1981; Manimekalan 1998), Neolissochilus (Rainboth 1985; Talwar \& Jhingran 1991; Devi et al. 1996; Pethiyagoda et al. 2012), and Barbodes (Wu 1977; Zhu 1995; Chen et al. 1999).

Our study shows that the correct generic allocation of the species is Neolissochilus (see Fig. 1) and not Barbodes s.s. (after Kottelat 2013) as mentioned in public databases like Catalog of Fishes (Eschemeyer 2014) and FishBase (Froese \& Pauly 2014). The N. wynaadensis sequences (co1 and cytb) formed a distinct clade closely related to other Neolissochilus species such as $N$. hexagonolepis, $N$. hexastichus and $N$. stracheyi. The closest genus related to Neolissochilus is Tor (Fig. 1a,b). Endemic large barbs of the Western Ghats (Hypselobarbus and Lepidopygopsis) also formed a monophyletic group along with Tor and Neolissochilus.

Rainboth (1985) suggested the possibility of the presence of more than one species of Neolissochilus per drainage based on the information available from the eastern part (i.e., Southeast Asia) of its distribution. However, our results on the biometrics as well as mitochondrial co1 and cytb gene sequences of $N$. wynaadensis collected from Wayanad (type locality) and two locations in Kodagu (=Coorg) are similar (see Table 2, 4 and Fig 1a,b) and suggest that there is only one species within the upper Cauvery drainage (Wayanad and Kodagu). The morphometric characters of the fish analysed in the present paper, are also consistent with those recorded by Arunachalam et al. (2005) from Abbey Falls. It is to be noted here that, similar to other large barbs of Western Ghats (see Knight et al. 2013 a,b; Ali et al. $2013 \mathrm{a}, \mathrm{b})$, N. wynaadensis also has a wide range of lateral line scale counts (26-29).

Currently, only two species of Neolissochilus are known from peninsular India and the Western Ghats, $N$. bovanicus and $N$. wynaadensis. The following names, viz., Neolissochilus tamiraparaniensis, N. acutirostris, N. microphthalmus, N. capudelphinus, N. minimus and $N$. anamalaiensis, which are mentioned in some scientific and non-scientific literature, are unavailable and represent 'nomina nuda' (for details see Raghavan et al. 2013).

\section{Distribution}

Neolissochilus wynaadensis is endemic to the
Western Ghats of India (Dahanukar \& Raghavan 2013). The species has a restricted distribution (an area of occupancy of $1000 \mathrm{~km}^{2}$ ) occurring in the east flowing streams and rivers part of the larger Cauvery drainage, i.e., Kalindi Stream of Kabini River in Thirunelli; Noolpuzha Stream of Kabini River inside the Wayanad Wildlife Sanctuary, Kakkanhalla and Moyar tributaries inside the Mudumalai Wildlife Sanctuary, as well as streams near Vythiri in Wayanad, and Muvathoklu, Mukkodlu, Surlabi, Bhagamandala and Abbey falls in Kodagu (see Image 3; Table 5). In Kodagu, N. wynaadensis has also been recorded in Hamyala (Images 4, 5) and Kakkehole (Steven Lockett, pers. comm. 2013). However, no voucher specimens are available. The species is currently known between the altitudinal range 400-1100 m.

The fact that the species has a very restricted distribution, and is confined to only a few tributaries/ streams in its range is additionally evident from the studies of Johnson \& Arunachalam (2009) (studies conducted in 2001-2002) where they did not record N. wynaadensis from two tributaries (Thalipuzha and Bavalipuzha) of the east flowing Cauvery in Wayanad District.

Abraham (2011), mentions that the fish also occurs in the Chooralmala and Kanthampara areas in Wayanad (part of the west flowing Chaliyar River system), without providing any reference. The author also mentions (a personal communication; see http://www.iucnredlist. org/details/172429/0) that the species occurs in the Periya Forest Range near Mananthavady, Wyanad. It is to be noted that, in a comprehensive study of the fishes of Nilgiri Biosphere Reserve including parts of Wayanad and upper reaches of Chaliyar (Easa \& Basha 1995; Easa \& Shaji 1997), not a single specimen of $N$. wynaadensis was collected from Chooralmala and Kanthampara (see Easa \& Basha 1995; Table 10; p 29), suggesting that the species could be restricted to only the east flowing drainages (Easa \& Shaji 1997). Therefore, in the absence of any references to the records, and actual voucher specimens, it is premature to conclude that $N$. wynaadensis occurs in the west flowing drainages as suggested by Abraham (2011).

Arunachalam et al. (2005) mentioned that $N$. wynaadensis occurs in Vattapoil in Wayanad District by citing Gopi (2000). This record may however be based on the personal examination of voucher specimens (ZSI/ WRS Calicut 6868) collected from this location, rather than as mentioned by Gopi (2000). This is because, Gopi (2000), in his review on the fishes of Kerala, does not mention such a location and only records this species from Thirunelli and Vythiri (see p 62 and 71). 


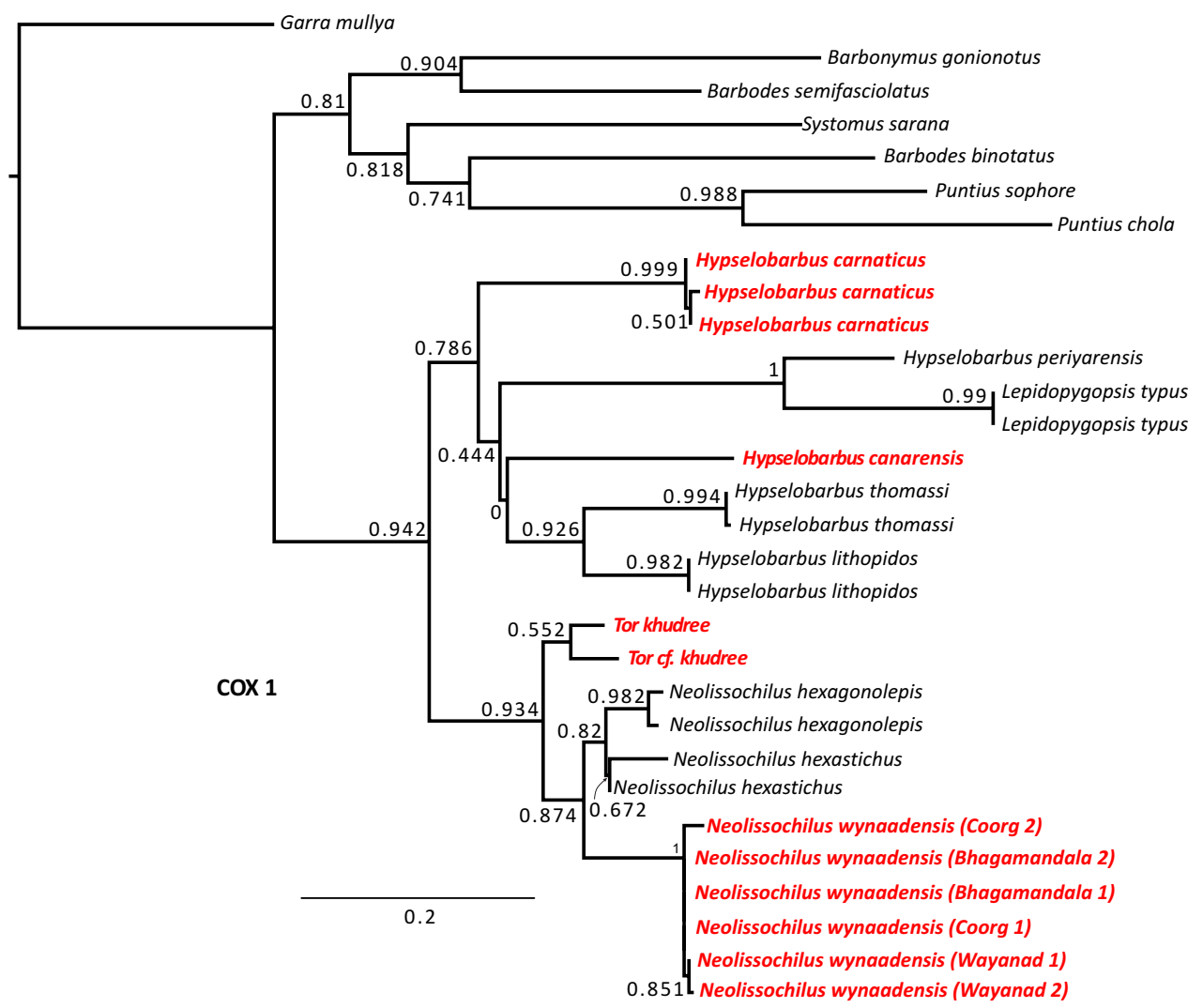

b

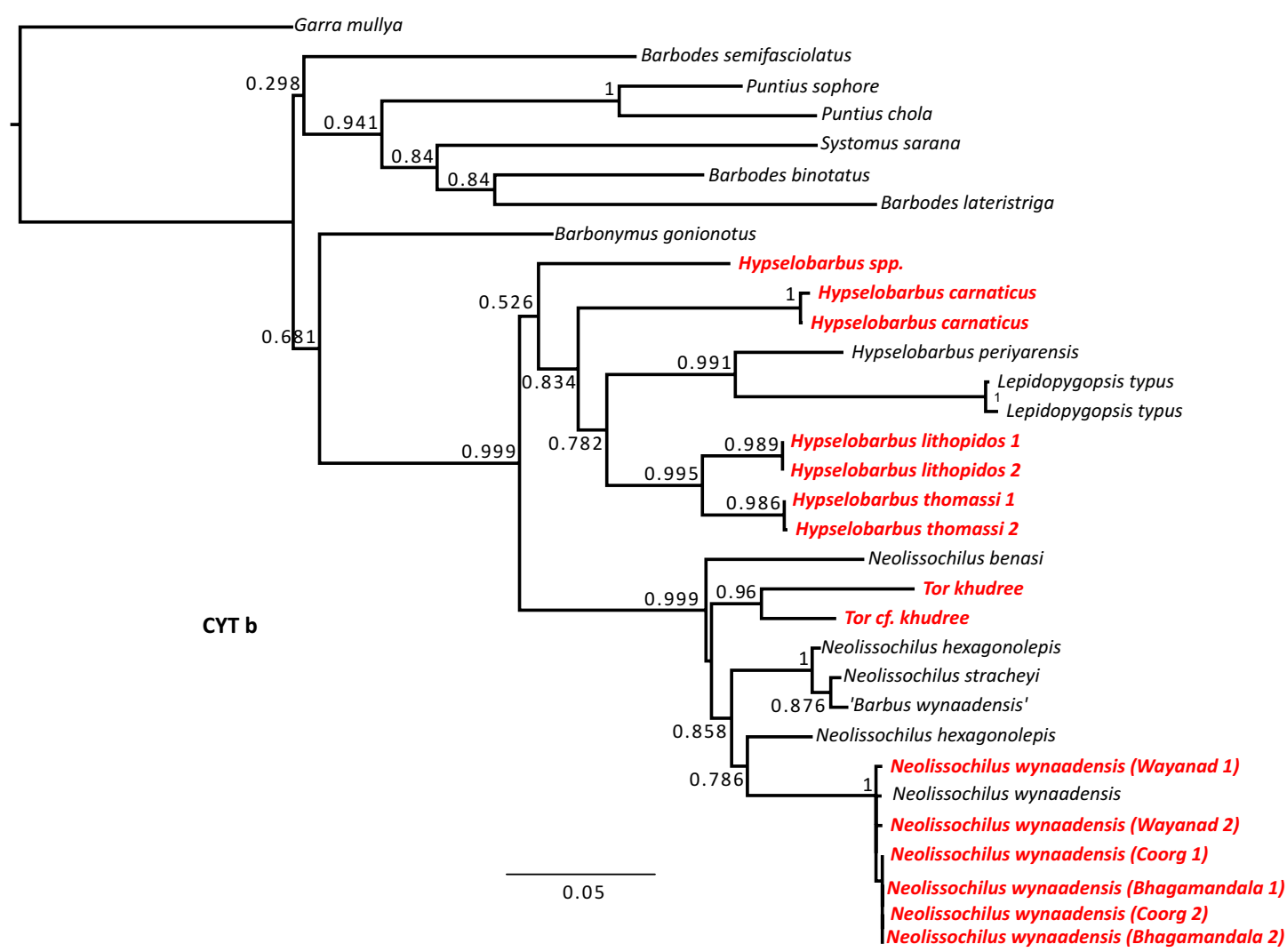

Figure 1. Maximum Likelihood tree using (a) mitochondrial co1 and (b) cytb gene sequences showing the identity and phylogenetic position of Neolissochilus wynaadensis 
Table 3. Details of co1 and cytb sequences used for the phylogenetic analyses presented in Fig. 1a and b.

\begin{tabular}{|c|c|c|c|}
\hline $\begin{array}{l}\text { Genbank Accession } \\
\text { Number }\end{array}$ & Species & Location & Remarks \\
\hline \multicolumn{4}{|l|}{ Co1 } \\
\hline KJ702313 & Neolissochilus wynaadensis & Thirunelli, Kabini River, India & Putative topotype \\
\hline KJ702314 & Neolissochilus wynaadensis & Thirunelli, Kabini River, India & Putative topotype \\
\hline KJ702312 & Neolissochilus wynaadensis & Mukkodlu, Cauvery River, Kodagu, India & \\
\hline KJ702317 & Neolissochilus wynaadensis & Mukkodlu, Cauvery River, Kodagu, India & \\
\hline KJ702315 & Neolissochilus wynaadensis & Bhagamandala, Cauvery River, Kodagu, India & \\
\hline KJ702316 & Neolissochilus wynaadensis & Bhagamandala, Cauvery River, Kodagu, India & \\
\hline EU714098 & Neolissochilus hexagonolepis & Ziyavarali River, Arunachal Pradesh, India & \\
\hline JX127231 & Neolissochilus hexagonolepis & India & \\
\hline JX127239 & Neolissochilus hexastichus & India & \\
\hline KF410988 & Neolissochilus hexastichus & India & \\
\hline NC_008655 & Barbonymus gonionotus & Mekong, Thailand & \\
\hline NC_020096 & Puntius semifasciolatus & Taiwan & \\
\hline JX983460 & Systomus sarana & Narmada River & \\
\hline JN646096 & Puntius binotatus & Malaysia & \\
\hline HM057185 & Puntius sophore & India & \\
\hline JN815309 & Puntius chola & India & \\
\hline KJ702311 & Hypselobarbus carnaticus & Cauvery, India & Putative topotype \\
\hline KJ702319 & Hypselobarbus carnaticus & Cauvery, India & Putative topotype \\
\hline KJ702320 & Hypselobarbus carnaticus & Cauvery, India & Putative topotype \\
\hline KF113559 & Hypsleobarbus periyarensis & Periyar, India & Putative topotype \\
\hline KF113553 & Lepidopygopsis typus & Periyar, India & Putative topotype \\
\hline KF113554 & Lepidopygopsis typus & Periyar, India & Putative topotype \\
\hline KJ702321 & Hypselobarbus canarensis & Kumaradhara, Karnataka, India & Putative topotype \\
\hline KF955536 & Hypselobarbus thomassi & Vettilapara, Chalakudy River, India & \\
\hline KF955539 & Hypselobarbus thomassi & Rosemalai, Kallada River, India & \\
\hline KF955537 & Hypselobarbus lithopidos & Chandragiri River, India & Putative topotype \\
\hline KF955538 & Hypselobarbus lithopidos & Chandragiri River, India & Putative topotype \\
\hline KJ702318 & Tor khudree & Pune, India & Putative topotype \\
\hline KJ702322 & Tor cf. khudree & Chalakudy, India & \\
\hline JX074155 & Garra mullya & India & \\
\hline \multicolumn{4}{|l|}{ Cytb } \\
\hline KJ702324 & Neolissochilus wynaadensis & Thirunelli, Kabini River, India & Putative topotype \\
\hline KJ702325 & Neolissochilus wynaadensis & Thirunelli, Kabini River, India & Putative topotype \\
\hline KJ702323 & Neolissochilus wynaadensis & Mukkodlu, Cauvery River, Kodagu, India & \\
\hline KJ702328 & Neolissochilus wynaadensis & Mukkodlu, Cauvery River, Kodagu, India & \\
\hline KJ702326 & Neolissochilus wynaadensis & Bhagamandala, Cauvery River, Kodagu, India & \\
\hline KJ702327 & Neolissochilus wynaadensis & Bhagamandala, Cauvery River, Kodagu, India & \\
\hline JN863594 & Neolissochilus wynaadensis & India & \\
\hline JX097077 & Neolissochilus hexagonolepis & Not mentioned & \\
\hline KC696525 & Neolissochilus hexagonolepis & Not mentioned & \\
\hline EF588164 & Neolissochilus stracheyi & Not mentioned & \\
\hline KC696524 & Barbus wynaadensis & Not mentioned & Misidentification ${ }^{1}$ \\
\hline
\end{tabular}




\begin{tabular}{|c|c|c|c|}
\hline $\begin{array}{l}\text { Genbank Accession } \\
\text { Number }\end{array}$ & Species & Location & Remarks \\
\hline KC696527 & Neolissochilus benasi & Not mentioned & \\
\hline NC_008655 & Barbonymus gonionotus & Mekong, Thailand & \\
\hline FJ667563 & Puntius semifasciolatus & China: Hueidong & \\
\hline GU826667 & Barbodes lateristiga & Not mentioned & \\
\hline GU826629 & Barbodes binotatus & Not mentioned & \\
\hline HM010726 & Systomus sarana & Narmada River & \\
\hline EU241461 & Puntius sophore & India & \\
\hline JQ795436.1 & Puntius chola & India & \\
\hline KJ702329 & Hypselobarbus carnaticus & Cauvery, India & Putative topotype \\
\hline KJ702331 & Hypselobarbus carnaticus & Cauvery, India & Putative topotype \\
\hline KF113565 & Hypsleobarbus periyarensis & Periyar, India & Putative topotype \\
\hline KF113567 & Lepidopygopsis typus & Periyar, India & Putative topotype \\
\hline KF113569 & Lepidopygopsis typus & Periyar, India & Putative topotype \\
\hline KJ702333 & Hypselobarbus thomassi & Vettilapara, Chalakudy River, India & \\
\hline KJ702334 & Hypselobarbus thomassi & Rosemalai, Kallada River, India & \\
\hline KJ702335 & Hypselobarbus lithopidos & Chandragiri River, India & Putative topotype \\
\hline KJ702336 & Hypselobarbus lithopidos & Chandragiri River, India & Putative topotype \\
\hline KJ702330 & Tor khudree & Pune, India & Putative topotype \\
\hline KJ702337 & Tor cf. khudree & Chalakudy, India & \\
\hline KJ702332 & Hypselobarbus sp. & Kumaradhara, South Canara & \\
\hline JX074237 & Garra mullya & India & \\
\hline
\end{tabular}

Abraham (2011) mentions about a record of $N$. wynaadensis from Bhadra River, citing Shahnawaz et al. (2009 sic) (note that the correct year should have been 2010). However a perusal of the original paper by Shahnawaz et al. (2010) reveals no such record. Similarly, although Pillai (1929) and Hora \& Law (1941) recorded Barbus wynaadensis from Travancore in southern Kerala, it is highly unlikely that the species occurs in the region. The record by Pillai (1929) from Tenmalai was also doubted by Menon (2004). In all probability, the specimen misidentified as Barbus wynaadensis from Travancore could be the fish currently known as 'Barbodes' carnaticus.

Neolissochilus wynaadensis was reported from Mula-Mutha River of Pune by Tonapi \& Mulherkar (1963). However, this record was doubted by Kharat et al. (2001, p 47). Similarly, the records of $N$. wynaadensis from China (Wu 1964, cited in Talwar \& Jhingran 1991), especially from the Yunnan region (Wu 1977, cited in Chen et al. 1999; Yang \& Chen 1994; Jing et al. 2013; also see cytb sequence KC696524 in GenBank) are 'at best' misidentifications, and may in all probability be $N$. hexagonolepis, N. stracheyi (see Fig 1) or an undescribed species similar to it. The examination of the specimen,
KIZ8110101 (see Yang \& Chen 1994) at the Kunming Institute of Zoology, China will help clear the exact identity of the 'Barbodes wynaadensis' recorded from the rivers in Yunnan.

Further studies are, however, required to understand the diversity of this genus especially from the southern regions of the Western Ghats from where many 'nomina nuda' under the genus Neolissochilus (see Raghavan et al. 2013) as well as previous records (Pillai 1929; Hora \& Law 1941) of $N$. wynaadensis are available. There is specifically a need to examine specimens identified and catalogued in various museums, as Tor species/Mahseer from various regions south of the Palakkad Gap.

\section{Population status}

Neolissochilus wynaadensis has been considered to be a very rare species (Gopi 2000; Easa \& Shaji $1997)$, as it was not recorded in many collections from Wayanad during 1999-2004 and in 2008 (Abraham 2011). Although not backed by any scientific data, global populations of this species were considered to have reduced by $80 \%$ during $2000-2010$, and are still declining (See Abraham 2011).

Our field surveys in Thirunelli in April 2004 


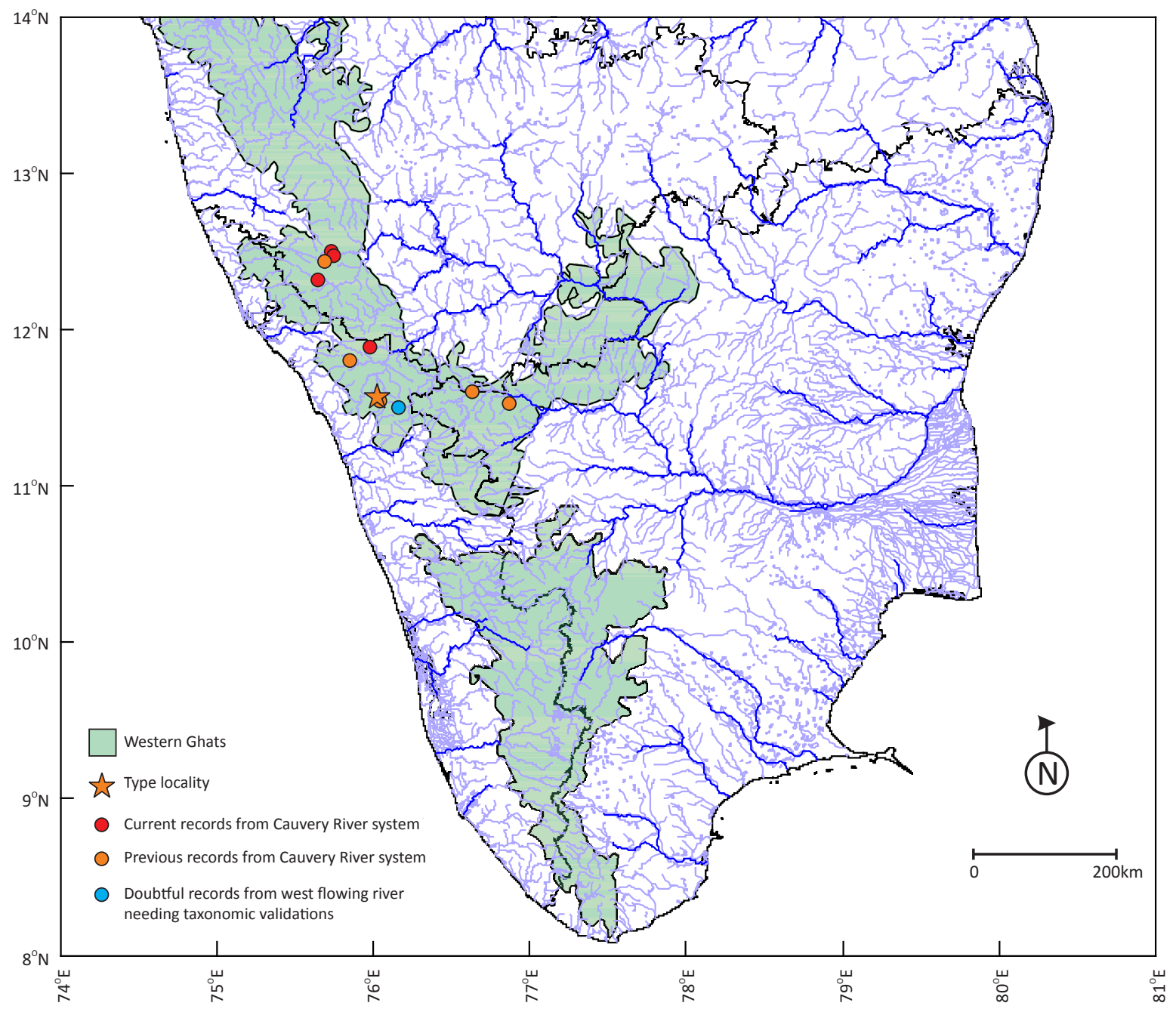

Image 3. Distribution of Neolissochilus wynaadensis in Western Ghats

Table 4. Table showing the 'raw' genetic distances between the specimens of Neolissochilus wynaadensis collected from different locations; The values for genetic distances with co1 is shown above diagonals (lighter shade) and cytb is shown below diagonals (darker shade).

\begin{tabular}{|c|c|c|c|c|c|c|c|}
\hline & KJ702312 & KJ702317 & KJ702315 & KJ702316 & KJ702313 & KJ702314 & co1 \\
\hline KJ702323 & -- & 0.007 & 0 & 0 & 0.002 & 0.003 & KJ702312 \\
\hline KJ702328 & 0 & -- & 0.007 & 0.007 & 0.008 & 0.010 & KJ702317 \\
\hline KJ702326 & 0 & 0 & -- & 0 & 0.002 & 0.002 & KJ702315 \\
\hline KJ702327 & 0 & 0 & 0 & -- & 0.002 & 0.002 & KJ702316 \\
\hline KJ702324 & 0.003 & 0.003 & 0.003 & 0.003 & -- & 0.002 & KJ702313 \\
\hline KJ702325 & 0.004 & 0.004 & 0.004 & 0.004 & 0 & - & KJ702314 \\
\hline cytb & KJ702323 & KJ702328 & KJ702326 & KJ702327 & KJ702324 & KJ702325 & \\
\hline
\end{tabular}

(Unpublished), and recently in October 2013 (vouchers mentioned in the present paper) led to the collection of only three specimens, while those in Vythiri in April 2004 did not yield any. Nevertheless, there are fairly good populations in Kodagu District of Karnataka State as evident from large shoals inhabiting the streams and rivers where they were occur. A large group (probably in hundreds) of $N$. wynaadensis were seen in a single splash pool near Muvathoklu where they are protected in a sacred grove (Devarkaadu). 
Table 5. Previous records of Neolissochilus wynaadensis from the Western Ghats

\begin{tabular}{|l|l|}
\hline Location/River & References \\
\hline Vythiri, Wayanad & $\begin{array}{l}\text { Day (1873, 1878, 1889); Easa \& Basha } \\
\text { (1995); Shaji \& Easa (1995); Kurup et al. } \\
\text { (2004) }\end{array}$ \\
\hline${\text { Tenmalai, Travancore }{ }^{1}}^{\text {Pillai (1929) }}$ \\
\hline Travancore $^{1}$ & Hora \& Law (1941) \\
\hline Pune $^{1}$ & Tonapi \& Mulherkar (1963) \\
\hline Kakkanhalla, Mudumalai & Manimekalan (1998), Yazdani et al. (2001) \\
\hline Moyar, Mudumalai & Manimekalan (1998), Yazdani et al. (2001) \\
\hline Arunagiri, Wayanad & Kurup et al. (2004) \\
\hline Abbey falls, Madikeri, Kodagu & Arunachalam et al. (2005) \\
\hline Kunnumbatta, Wayanad & Euphrasia et al. (2006) \\
\hline Kattikunnu, Wayanad & Euphrasia et al. (2006) \\
\hline C.C. Puzha, Wayanad & Euphrasia et al. (2006) \\
\hline Appenkappa, Wayanad & Euphrasia et al. (2006) \\
\hline Hamyala, Kodagu & Steven Lockett (2013) ${ }^{1}$ \\
\hline Kakehole, Kodagu & Steven Lockett (2013) ${ }^{1}$ \\
\hline Chooralmala, Wayanad & Abraham (2011) ${ }^{2}$ \\
\hline Kanthampara, Wayanad & Abraham (2011) ${ }^{2}$ \\
\hline
\end{tabular}

${ }^{1}$ doubtful records; ${ }^{2}$ personal communications

\section{Habitat and Ecology}

Neolissochilus wynaadensis prefers fast flowing upland streams and rivers where they occur in both rocky pools (Abraham 2011) as well as riffles (Kurup et al. 2004). The pool-riffle habitats have a moderate flow velocity and provide good hiding places for the species. These habitats are also frequented by riffle beetles and chironomids that form the major food for N. wynaadensis (Manojkumar \& Kurup 2002). Kurup et al. (2004) provides information on several microhabitat variables in the locations frequented by $N$. wynaadensis. Habitats in the sites from where $N$. wynaadensis was recorded in the present study are shown in Images 6, 7 and 8 . It has also been suggested that $N$. wynaadensis are long range migrants that travel to the upper reaches of rivers for spawning (Menon 2004).

\section{Phylogenetic position}

The Neolissochilus from peninsular India $(N$. wynaadensis) forms a monophyletic grouping with other Neolissochilus species from northeastern India and Southeast Asia (Fig 1a,b). Also, the specimens of Neolissochilus found in various locations in Kodagu (=Coorg, in Bhagamandala and Mukkodlu), were genetically similar to those that occur in the type locality of the species (i.e., Wayanad) (also see Table 4). The

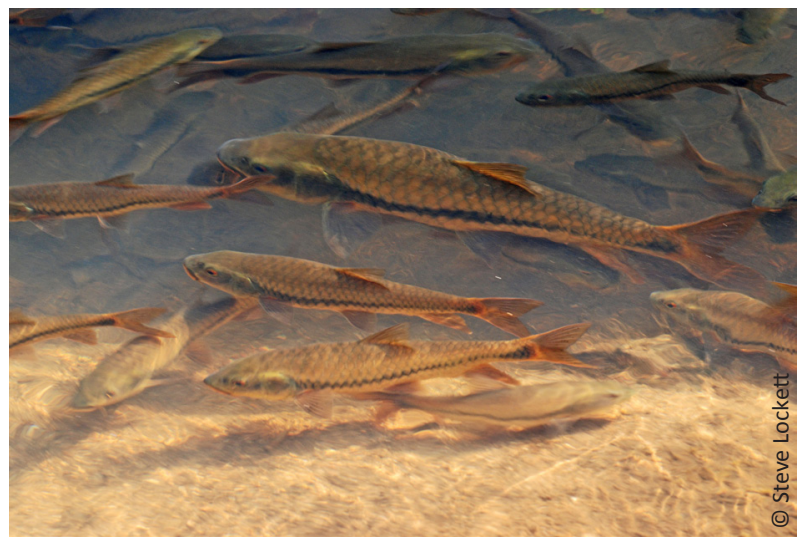

Image 4. Neolissochilus wynaadensis at Hamyala, Kodagu

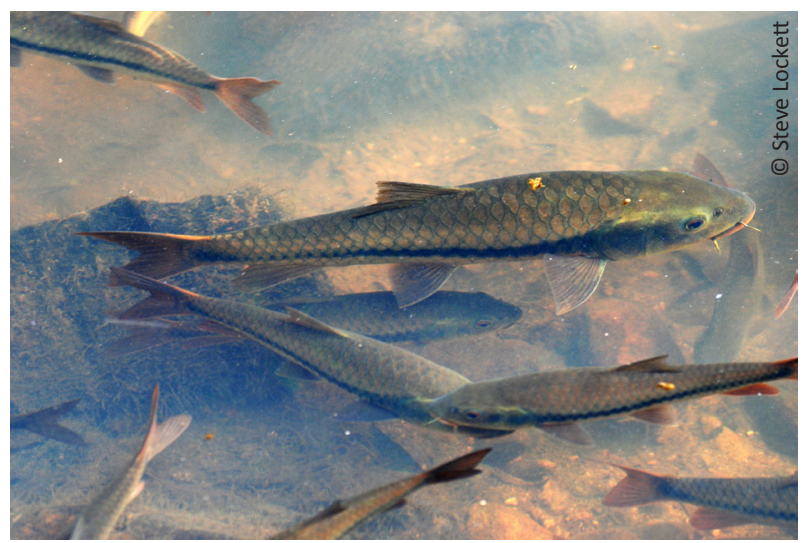

Image 5. Neolissochilus wynaadensis at Hamyala, Kodagu

discontinuous distribution of the genus Neolissochilus (Sundaland, Indo Burma, Eastern Himalaya and Western Ghats) could also form the basis for interesting biogeographic hypothesis testing; for instance, to check the scenario of 'true disjuncts' (see Dahanukar et al. 2013 and references therein). On the other hand, detailed anatomical and morphological analysis is needed to ascertain if the Western Ghats representatives of the genus are 'false disjuncts' and need a separate generic allocation. Such biogeographic and evolutionary questions should however be validated with larger multi-locus datasets.

\section{Threats and conservation}

Anthropogenic threats including habitat destruction as well as pollution caused by the discharge of fertilizers, pesticides and other chemical effluents from surrounding plantations and sand mining have been reported from the habitats frequented by the species (Abraham 2011). There is no data to show that this species is being 


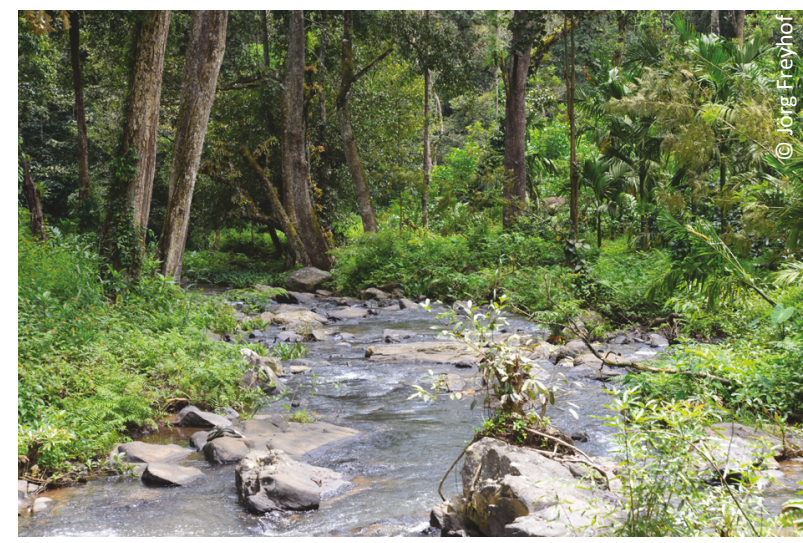

Image 6. Habitat of Neolissochilus wynaadensis near Mukkodlu, Kodagu, Karnataka [Image taken on 07.x.2013]

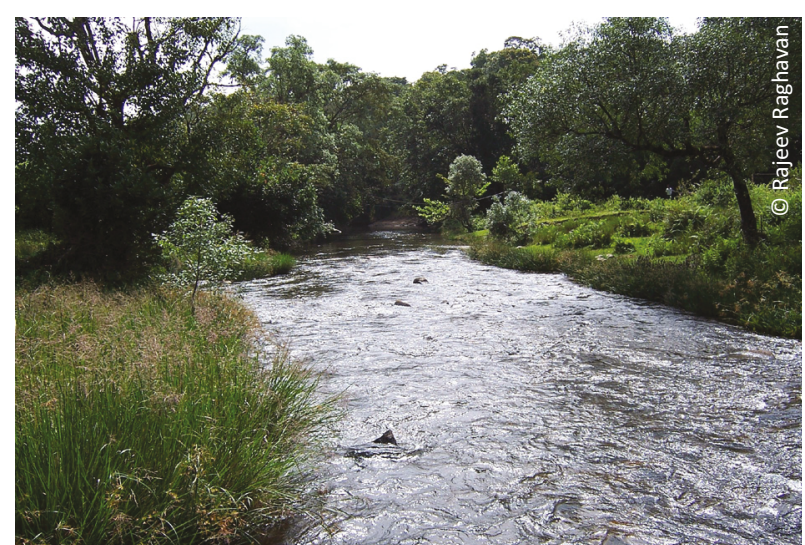

Image 8. Habitat of Neolissochilus wynaadensis near Thirunelli, Wayanad, Kerala [Image taken in April 2004]

exploited as a food fish (Abraham 2011), but given its size, it is likely to be harvested by local communities. Overall, there is a need for greater understanding of the specific threats, their intensity and the impacts they have on the survival of the species.

Much of the known range of $N$. wynaadensis is outside protected areas. Currently, Wayanad Wildlife Sanctuary in Kerala and Mudumalai Wildlife Sanctuary in Tamil Nadu are the only protected areas where the species occur. However, an alternate protected area system in the form of sacred groves, (Devarkaadu) exists in Kodagu, Karnataka. Streams flowing through these sacred groves harbour good populations of $N$. wynaadensis which are protected (for e.g., in Mukkodlu, Muvathoklu and Surlabi regions) by the local communities.

Currently, N. wynaadensis has been listed as 'Critically Endangered' (Abraham 2011) in the IUCN Red List of Threatened Species. Additional information on distribution and threats as documented in the present

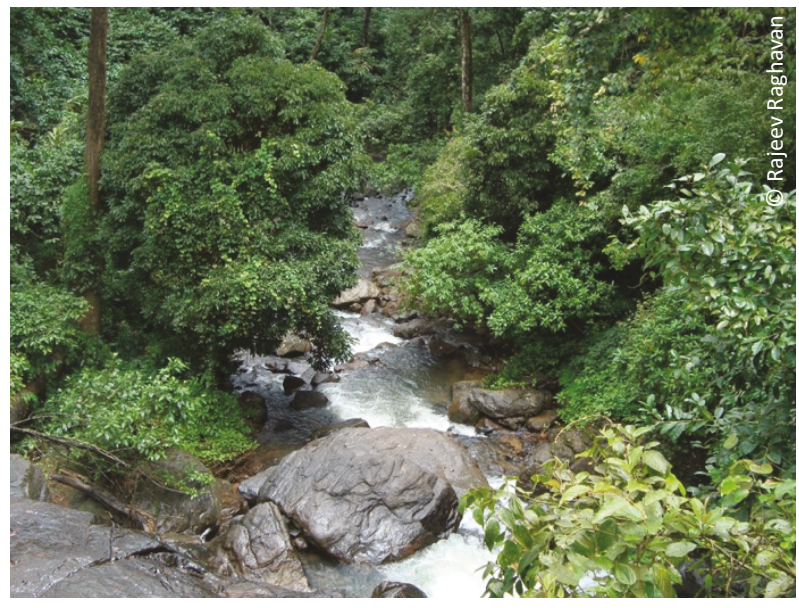

Image 7. Habitat of Neolissochilus wynaadensis near Surlabi, Kodagu, Karnataka [Image taken on 10.ix.2013]

paper has led to a scenario where the conservation status of the species needs to be revised. The proposed Red List Status of the species has been provided in Appendix 1.

\section{CONCLUSIONS}

Large cyprinids of the genus Tor, Neolissochilus, Hypselobarbus and 'Barbodes' comprise one of the most poorly known freshwater fishes of the Western Ghats, with very little information available on their diversity (both generic and specific) and distribution. Recent studies have helped to improve our knowledge on some genera (for e.g., Hypselobarbus) (see Ali et al. 2013a,b; Knight et al. 2013a,b,c), while others (Tor, Neolissochilus and Barbodes) remain understudied. Future research should be directed on these large barbs to understand in detail their taxonomy, diversity, distribution, population dynamics and stock structure and conservation. There is particularly a need to understand the identity of the barb described by Day (1877) as Barbus bovanicus, from the Bhavani River in the southern Western Ghats, which is currently considered to be a species of Neolissochilus (see Pethiyagoda et al. 2012).

\section{REFERENCES}

Abraham, R. (2011). Barbodes wynaadensis. In: IUCN 2013. IUCN Red List of Threatened Species. Version 2013.2. <www.iucnredlist.org>. Downloaded on 24 December 2013.

Ali, A., N. Dahanukar, A. Kanagavel, S. Philip \& R. Raghavan (2013a). Records of the endemic and threatened catfish, Hemibagrus punctatus from the southern Western Ghats with notes on its distribution, ecology and conservation status. Journal of Threatened 
Taxa 5(11): 4569-4578; http://dx.doi.org/10.11609/JoTT 03427.4569-78

Ali, A., S. Philip \& R. Raghavan (2013b). Back from obscurity: notes on the current distribution, threats and conservation status of a poorly known cyprinid, Hypselobarbus lithopidos (Day, 1874) from the Western Ghats of India. Journal of Threatened Taxa 5(13): 47434751; http://dx.doi.org/10.11609/JoTT.o3655.4743-51

Ali, A., S. Philip, N. Dahanukar, C.R. RenjithKumar, A. Bijukumar \& R. Raghavan (2013c). Distribution, threats and conservation status of Hypselobarbus thomassi (Day, 1874), a poorly known cyprinid fish of the Western Ghats freshwater ecoregion. Journal of Threatened Taxa 5(17): 5202-5213; http://dx.doi.org/10.11609/ JoTT. 03838.5202-5213

Arunachalam, M., M. Muralidharan, P. Sivakumar, R. Soranam \& M. Murugan (2005). New record of a rare barbin Neolissochilus wynaadensis (Day) from Abby Falls, Karnataka. Zoos' Print Journal 20(11): 2073-2074; http://dx.doi.org/10.11609/JoTT. ZPJ.1342.2073-4

Chen, X.Y., J.X. Yang \& Y.R. Chen (1999). A review of the cyprinoid fish genus Barbodes Bleeker, 1859 from Yunnan, China, with descriptions of two new species. Zoological Studies 38(1): 82-88.

Dahanukar, N. \& R. Raghavan (2013). Freshwater fishes of Western Ghats: Checklist v 1.0 August 2013. MIN - Newsletter of IUCN SSC/ WI Freshwater Fish Specialist Group - South Asia and the Freshwater Fish Conservation Network of South Asia (FFCNSA) 1: 6-16.

Dahanukar, N., S. Philip, K. Krishnakumar, A. Ali \& R. Raghavan (2013). The phylogenetic position of Lepidopygopsis typus (Teleostei: Cyprinidae), a monotypic freshwater fish endemic to the Western Ghats of India. Zootaxa 3700(1): 113-139. http://dx.doi. org/10.11646/zootaxa.3700.1.4

Day, F. (1873). On some new fishes of India. The Journal of the Linnean Society of London 11: 524-530. http://dx.doi. org/10.1111/j.1096-3642.1873.tb01674.x

Day, F. (1878). The Fishes of India; Being A Natural History of The Fishes Known to Inhabit the Seas and Freshwaters of India, Burma, and Ceylon - Part 4. Bernard Quatrich, London, i-xx + 553-579, pls 139-195.

Day, F. (1889). Fishes. In: Blanford, W.T. (ed). The Fauna of British India including Ceylon and Burma. Taylor \& Francis, London. v. 1: 1-xviii $+1-548$.

Devi, K.R., T.J. Indra \& K.G. Emiliyamma (1996). On the fish collections from Kerala deposited in the Southern Regional Station, Zoological Survey of India, by NRM, Stockholm. Records of the Zoological Survey of India 95(3-4): 129-146

Easa, P.S. \& S.C. Basha (1995). A Survey of The Habitat and Distribution of Stream Fishes in the Kerala Part of Nilgiri Biosphere Reserve. Kerala Fisheries Research Institute Research Report No. 104, 87pp.

Easa, P.S. \& C.P. Shaji (1997). Freshwater fish diversity in the Kerala part of the Nilgiri Biosphere Reserve. Current Science 73(2): 180182.

Euphrasia, C.J., K.V. Radhakrishnan \& B.M. Kurup (2006). The threatened freshwater fishes of Kerala, India, pp. 570-588. In: Kurup, B.M. \& K. Ravindran (eds.). Sustain Fish. School of Industrial Fisheries, Cochin University of Science and Technology, Cochin, India.

Gopi, K.C. (2000). Freshwater fishes of Kerala State, pp. 5676. In: Ponniah, A.G. \& A. Gopalakrishnan (eds.). Endemic Fish Diversity of Western Ghats. NBFGR-NATP, India.

Hora, S.L. \& N.C. Law (1941). The freshwater fishes of Travancore. Records of Indian Museum 43: 233-256.

Jayaram, K.C. (1981). The Freshwater Fishes of India, Pakistan, Bangladesh, Burma and Sri Lanka - A Handbook. Zoological Survey of India, i-xxii+475pp, pls. 1-13.

Jhingran, V.G. (1977). Fish and Fisheries of India. Hindustan Publishing Corporation, 953pp.

Jing, W., X.Y. Wu, Z.M. Chen, Z.P. Yue, W. Ma, S.Y. Chen, H. Xiao, R.W. Murphy, Y.P. Zhang, R.G. Zan \& J. Luo (2013). Molecular phylogeny of European and African Barbus and their West Asian relatives in the Cyprininae (Teleostei: Cypriniformes) and orogenesis of the
Qinghai-Tibetan Plateau. Chinese Science Bulletin 58 (31): 37383746. http://dx.doi.org/10.1007/s11434-013-5878-z

Johnson, J.A. \& M. Arunachalam (2009). Diversity, distribution and assemblage structure of fishes in streams of southern Western Ghats, India. Journal of Threatened Taxa 1(10): 507-513; http:// dx.doi.org/10.11609/JoTT.o2146.507-13

Khaironizam, M.Z. (2010). Some biological aspects of Neolissochilus spp. (Teleostei: Cyprinidae) from Peninsular Malaysia. PhD Thesis. University of Malaya, Kuala Lumpur, 215pp.

Kharat, S.S., N. Dahanukar \& R. Raut (2001). Decline of fresh-water fish of Pune urban area. Journal of Ecological Society 13/14: 46-51.

Knight, J.D.M., A. Rai \& R.K.P. D'souza (2013a). Re-description of Hypselobarbus lithopidos (Teleostei: Cyprinidae), based on its rediscovery from the Western Ghats, India, with notes on $H$. thomassi. Journal of Threatened Taxa 5(13): 4734-4742; http:// dx.doi.org/10.11609/JoTT.03602.4734-42

Knight, J.D.M., A. Rai \& R.K.P. D'souza (2013b). On the identities of Barbus mussullah Sykes and Cyprinus curmuca Hamilton with notes on the status of Gobio canarensis Jerdon (Teleostei: Cyprinidae). Zootaxa 3750(3): 201-215; http://dx.doi.org/10.11646/ zootaxa.3750.3.1

Knight, J.D.M., A. Rai \& R.K.P. D'souza (2013c). Rediscovery of Hypselobarbus pulchellus, an endemic and threatened barb (Teleostei: Cyprinidae) of the Western Ghats, with notes on $H$. dobsoni and H. jerdoni. Journal of Threatened Taxa 5(17): 51945201; http://dx.doi.org/10.11609/JoTT.03686.5194-201

Kottelat, M. (2013). The fishes of the inland waters of South East Asia: a catalogue and core bibliography of the fishes known to occur in freshwaters, mangroves and estuaries. Raffles Bulletin of Zoology (Supplement) 27: 1-663.

Kurup, B.M., K.V. Radhakrishnan \& T.G. Manojkumar (2004). Biodiversity Status of Fishes Inhabiting Rivers of Kerala (South India) With Special Reference to Endemism, Threats and Conservation Measures. In: Welcomme, R.L \& T. Petr. (eds.). Proceedings of the Second International Symposium on the Management of Large Rivers for Fisheries 2 (LARS2), Cambodia, 310pp.

Manimekalan, A. (1998). The fishes of Mudumalai Wildlife Sanctuary, Tamil Nadu, South India. Journal of the Bombay Natural History Society 95(3): 431-443.

Manojkumar, T.G. (2006). Fish habitats and species assemblages in the selected rivers of Kerala and investigation on life history traits of Puntius carnaticus (Jerdon, 1849). PhD Thesis. Cochin University of Science and Technology, Kochi, India.

Manojkumar, T.G. \& B.M. Kurup (2002). Fish habitat diversity and species assemblage structure with reference to five major river systems of Kerala, pp. 141-150. In: Riverine and Reservoir Fisheries of India. Boopendranath, M.R., B. Meenakumari., J. Joseph., T.V. Sankar., P. Pravin \& L. Edwin (eds.). Society for Fisheries Technology, Cochin and Central Institute of Fisheries Technology, Cochin.

Menon, A.G.K. (1999). Check list-fresh water fishes of India. Records of the Zoological Survey of India. Miscellaneous Publication, Occasional Paper No. 175: i-xxviii+1-366.

Menon, A.G.K. (2004). Threatened fishes of India and their conservation. Zoological Survey of India, 170pp.

Pethiyagoda, R., M. Meegaskumbura \& K. Maduwage (2012). A synopsis of the South Asian fishes referred to Puntius (Pisces: Cyprinidae). Ichthyological Exploration of Freshwaters 23(1): 69-95.

Pethiyagoda, R., A. Silva, K. Maduwage \& M. Meegaskumbura (2008). Puntius kelumi, a new species of cyprinid fish from Sri Lanka (Teleostei: Cyprinidae). Ichthyological Exploration of Freshwaters 19(3): 201-214

Pillai, R.S.N. (1929). A list of fishes taken in Travancore from 19011915. Journal of the Bombay Natural History Society 33(2): 347-379.

Raghavan, R., N. Dahanukar, S. Philip, K. Krishnakumar \& A. Ali (2013). Phantom references, nomina nuda and the dilemma of freshwater fish taxonomy in India. Current Science 104(10): 1277-1279.

Rainboth, W.J. (1995). Neolissochilus, a new genus of South Asian cyprinid fishes. Beaufortia 35 (3): 25-35.

Shahnawaz, A., M. Venkateshwarlu, D.S. Somashekar \& K. Santosh 


\section{Appendix 1. Proposed Red List Status for Neolissochilus wynaadensis}

Current Status: Critically Endangered A2ace

Proposed Status: Vulnerable B1ab(iii)+2ab(iii)

Taxonomy

Scientific name: Neolissochilus wynaadensis Day (1873)

Common names: Wayanad Mahseer, Copper Mahseer (English); Wayanadan Kuyil, Manja Kadanna (Malayalam); Maara Meenu, Katli (Kannada)

Synonyms: Barbus wynaadensis, Puntius wynaadensis, Barbodes wynaadensis

Taxonomic notes: Neolissochilus wynaadensis was described by Day (1873) from the streams near Vythiri, Wayanad, Kerala State, India. The fish has been placed under different genera viz., Barbus, Puntius and Barbodes in the ichthyological literature. A detailed phylogenetic analysis (see present paper) revealed its affinity to, and supports its placement in the genus Neolissochilus.

\section{Assessment Information}

Red List category and criteria: Vulnerable B1ab(iii)+2ab(iii)

Justification: Neolissochilus wynaadensis is assessed as Vulnerable (B1ab(iii)+2ab(iii)) as it has an estimated EOO of not more than 8000 km², an $\mathrm{AOO}$ of not more than $1000 \mathrm{~km}^{2}$, and a restricted distribution as it occurs in only seven locations. The habitats where the species is known to occur is also greatly affected by deforestation, ongoing siltation and pollution caused by the discharge of fertilizers, pesticides and other chemical effluents from coffee and other plantations.

\section{Geographic range}

Range description: Endemic to the Western Ghats (Dahanukar \& Raghavan 2013), where they are currently known from the Cauvery river system in Wayanad (Kabini) and Kodagu (Manimekalan 1998; Yazdani et al. 2001; Kurup et al. 2004; Arunachalam et al. 2005; present paper) as well as streams in Mudumalai (Moyar and Kakanhalla). Its occurrence in the west flowing Chaliyar River in Kerala is likely, but needs confirmation. All other records, i.e. China (Wu 1964, cited in Talwar \& Jhingran 1991; Wu 1977, cited in Chen et al. 1999; Yang \& Chen 1994; Jing et al. 2013), Pune (Tonapi \& Mulherkar 1963), Travancore (Pillai 1929; Hora \& Law 1941) are considered to be misidentifications. The estimated (approximate) current extent of occurrence (EOO) is less than $8000 \mathrm{~km}^{2}$ and current (approximate) area of occupancy (AOO) no more than $1000 \mathrm{~km}^{2}$ (see map next page).

Countries: India (states of Karnataka, Kerala and Tamil Nadu)

Range Map: see Image 3

\section{Habitat and Ecology}

Habitat and Ecology: Known to occur in fast to moderately flowing streams and rivers flowing through low to mid elevation evergreen forests, where they are found in pool-riffle habitats with sand as the dominant substrate (Manojkumar \& Kurup 2002). The fish is known to attain sizes up to $250 \mathrm{~mm}$ (Menon 1999) but individuals above $170 \mathrm{~mm}$ are rare (Manojkumar 2006).

Systems: Freshwater

\section{Threats}

Major Threats: Habitat alteration and destruction as well as pollution caused by the discharge of fertilizers, pesticides and other chemical effluents from plantations are the most important threats to the species. Although, there is no data to show that this species is being exploited as a food fish, given its size, it is likely to be harvested by local (especially tribal) communities. In Kodagu, many of the streams in which $N$. wynaadensis occurs pass through coffee plantations and are likely to be under the threat of pesticide run-off.

\section{Population}

Population: No reliable estimates of the status or trends in populations are available. Streams flowing through the sacred groves in Kodagu are known to harbour high numbers of the species (Ali et al. 2014).

Population trend: Unknown

\section{Conservation}

Conservation action: No species specific conservation actions are currently in place. Except for the populations inside the Wayanad Wildlife Sanctuary in Kerala, and the Mudumalai Wildlife Sanctuary in Tamil Nadu, much of the range of this species (especially in Kodagu) is outside formal protected areas. However, many of the streams in Kodagu are part of sacred groves (Devarkaadu) or village temples, and so are protected. The project on 'Lost fishes of the Western Ghats' is involved in research, education and awareness on poorly known species of the region including $N$. wynaadensis. Increased survey efforts are needed in various parts of Kodagu as well as in the upper reaches of Chaliyar in the Chooralmala area of Kerala to confirm whether undiscovered populations exist. Education and awareness programs need to be carried out in close cooperation with the local self governments (Panchayath) in Kodagu. 


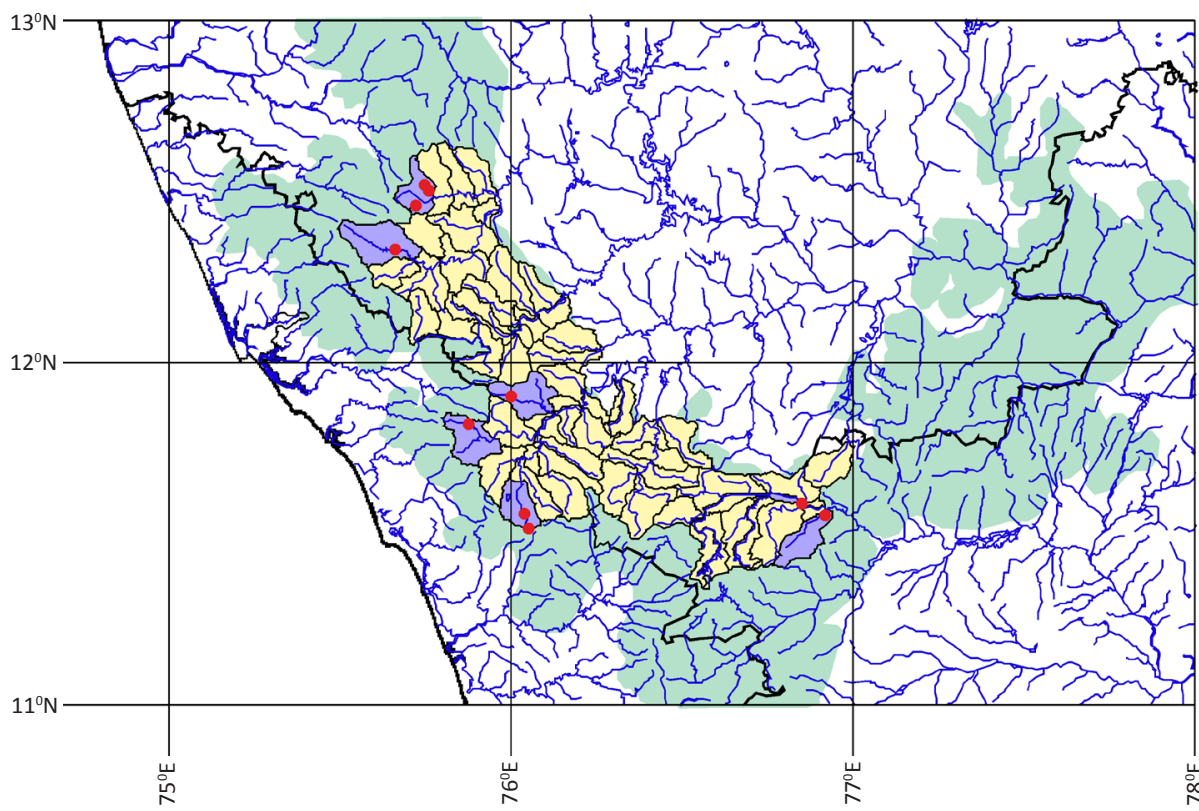

Map. Estimated extent of occurrence (EOO) and area of occupancy (AOO) of Neolissochilus wynaadensis

(2010). Fish diversity with relation to water quality of Bhadra River of Western Ghats (India). Environmenta Monitoring and Assessment 161(1-4): 83-91; http://dx.doi.org/10.1007/s10661-008-0729-0

Shaji, C.P. \& P.S. Easa (1995). Freshwater fish diversity in Wayanad, Kerala, south India. Journal of Zoological Society of Kerala 5(1\&2): 30-36.

Talwar, P.K. \& A.G. Jhingran (1991). Inland fishes of India and adjacent countries - 2 volumes. Oxford \& IBH Publishing Co. New Delhi, 1158pp.

Tonapi, G.T. \& L. Mulherkar (1963). Notes on the freshwater fauna of Poona. Proceedings of the Indian Academy of Sciences - Section B 58(4): 187-197.

Wu, X.W. (1964). The cyprinid fishes of China - Volume 1. Science Press, Shanghai, 228pp. [not referred to in original]

Wu, X.W. (1977). The Cyprinid Fishes of China - Volume 2. Science Technical Press, Shanghai, pp. 236-252 [not referred to in original]

Yazdani, G.M., K.R. Devi, M.B. Raghunathan \& D.F. Singh (2001). Fauna of Nilgiri Biosphere Reserve Pisces. Fauna of Conservation Area Series 11. Zoological Survey of India, 207-224.

Yang, J. \& Y. Chen (1994). Phylogeny and zoogeography of the cyprind genus Spinibarbus (Pisces: Cyprinidae). Zoological Research 15: 13-25.

Zhu, S.Q. (1995). Synopsis of freshwater fishes of China, 549p. [not referred to in original]

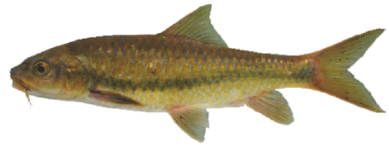

Point localities

Western Ghats

Known hydrobasins

Probable hydrobasins

Author Details: ANVAR ALI is interested in taxonomy and systematics of freshwater fishes of the Western Ghats.

NEELESH DAHANUKAR works in taxonomy, ecology and evolutionary biology of fishes and amphibians with emphasis on mathematical and statistical analysis.

SIBY PHILIP is interested in molecular phylogenetics, evolution and biogeography of freshwater fishes of the South Asia region.

K. KRISHNAKUMAR is interested in freshwater fish conservation with specific focus on alien invasive species. RAJEEV RAGHAVAN is interested in interdisciplinary research focused on generating information and developing methods to support conservation decision-making in freshwater ecosystems. 